
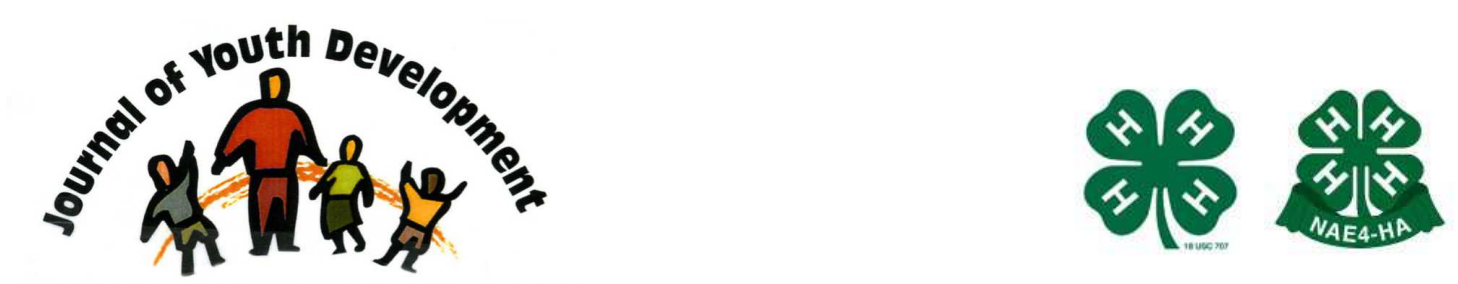

Bridging Research \& Practice

\title{
Lack of Parental Rules for Cell Phone Use among Low Income Mexican Descendent Adolescents
}

\author{
Christine Bracamonte Wiggs \\ College of Agriculture \& Life Sciences \\ The University of Arizona \\ Tucson, AZ \\ cbmonte@email.arizona.edu
}

Andrea J. Romero

College of Agriculture \& Life Sciences

The University of Arizona

Tucson, AZ

Michele Orduña

Family Studies \& Human Development

University of Arizona 


\title{
JOURNAL OF YOUTH DEVELOPMENT \\ bridging research and practice

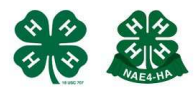

Article 130803RS002

\section{Lack of Parental Rules for Cell Phone Use among Low Income Mexican Descendent Adolescents}

\author{
Christine Bracamonte Wiggs and Andrea J. Romero \\ The University of Arizona \\ Michele Orduña \\ University of Arizona
}

\begin{abstract}
Youth have access to and utilize various types of technology at a growing rate. Cell phones are a portable way for adolescents to remain in constant contact with friends, parents, and others. While White youth are more likely to have a cell phone compared to Latino youth, the trends for cell phone use are similar among all teens with text messaging serving as the most popular means of communication. Despite their high volume of communication with others via cell phones, adolescents are likely to have little or no adult supervision while using technology. With a lack of parental supervision or awareness regarding youth technology use, adolescents may be especially vulnerable to cyberbullying and other negative health impacts. The current study investigates cell phone and texting use among a community sample of Latino adolescents and examines how parental rules regarding cell phone use influences adolescents' cell phone and texting behaviors.
\end{abstract}

\section{Introduction}

Youth have access to and utilize various types of technology including computers, the internet, and cell phones at a growing rate. According to the Pew Research Center (2011), cell phone ownership among adolescents rose from 45\% in 2004 to $77 \%$ in 2011 (Lenhart, 2012). While White youth are more likely to have a cell phone compared to Latino youth ( $81 \%$ versus $63 \%$ ), the trends for cell phone use are similar among all teens with text messaging serving as the most popular means of communication followed by cell calling (Lenhart, Ling, Campbell, \& Purcell, 2010). Cell phones are a portable way for adolescents to remain in constant contact with friends, parents, and others. Recent research conducted by the Pew Research Center (2011), found a majority of adolescents (63\%) reported exchanging daily text messages with 
people in their lives. Moreover, some youth proved to be prolific communicators, with $44 \%$ reporting sending 50 or more text messages a day (Lenhart, et al., 2010). Despite their high volume of communication with others via cell phone and text messages, adolescents are likely to have little or no adult supervision while using technology (Donahue, Haskins, \& Nightingale, 2008; Weisskirch, 2011; Weisskirch, 2009). With a lack of parental supervision or awareness regarding youth technology use, adolescents may be especially vulnerable to cyberbullying and other technology-related negative health impacts. In the current study we investigate cell phone and texting use among a community sample of Latino adolescents. Specifically, we investigate parental rules regarding cell phone use and how these rules relate to adolescents' cell phone and texting behaviors.

\section{Parental Monitoring and Cell Phones}

Parental monitoring has been defined as parent's monitoring of teen behavior, knowledge of their whereabouts, and knowledge of their friends (Patterson, Dearyshe, \& Ramsey, 1989). Parental monitoring specifically includes the setting of boundaries and enforcing of disciplinary consequences when necessary based on guidelines for acceptable behavior (Dishion, \& McMahon, 1998). However, recent work has also included aspects of parental-child positive communication as a source of knowledge and monitoring in a manner that is less "policing" and more rooted in positive familial relationships and trust (LeDoux, Miller, Choquet, \& Plant, 2002; Romero, \& Ruiz, 2007; Stattin, \& Kerr, 2000; Van Campen, \& Romero, 2012). In general, higher levels of parental monitoring are associated with increased self-esteem among youth as well as decreased levels of teen sexual activity, drug and alcohol use, rates of depression, and school dropout (Dishion, \& McMahon, 1998; Jacobson, \& Crockett, 2000; Pettit, \& Laird, 2002). Specifically, it is the parental involvement, communication and attachment that is associated with less risky behavior, particularly among ethnic minority adolescents (Bird, Canino, Davies, Zhang, Ramirez, \& Lahey, 2001; Dinh, Roosa, Tein, \& Lopez, 2002; Romero, \& Ruiz, 2007; Van Campen, \& Romero, 2012). Parental monitoring of cell phone use and texting behavior may help limit risky behaviors, such as inappropriate sexting, or texting while driving. It may also help create positive communication between parents and teens when parents use cell phones and texting as a means to communicate with children.

\section{Communication with Parents via Cell Phone}

There is evidence that parental use of texting can serve as an effective method to communicate with youth and maintain parental monitoring practices. For instance, in a study of immigrant Filipino mothers working abroad, the women relied on text messaging to interact with their children in real time and to maintain parenting practices (Uy-Tioco, 2007). Research with ethnic minority adolescents finds that the proximity of the value of familism (close family unity) can help protect adolescents from risky behaviors; it is unclear whether regular media communication can serve this function as well (Romero, \& Ruiz 2007). Adolescents with supportive communication from their family members are typically better able to refuse or avoid risky situations that may lead to substance use, risky sexual behavior, or violence (Capara, et al., 1998). However, there may be limitations on how effective cell phones can be for supporting parental monitoring. Weisskirch (2009) found that among White middle class youth, a high rate of parental monitoring via cell phone was associated with less truthfulness among adolescents. Thus, it is clear that research is needed to understand how parents and children are using media to stay in communication, particularly within the context of parental monitoring, which may serve to enforce rules, but also to help nurture positive communication in a means that is teenager-centric. 
There is limited evidence related to cell phone and texting use among low income and immigrant communities, especially with regard to parental monitoring practices about adolescent cell phone use. In the current study, we investigate the cell phone and texting practices of Mexican and American Indian adolescents from a low income community and examine their perceptions of parental monitoring of their cell phone use behaviors.

\section{Sample}

\section{Methods}

Seventy four $(\mathrm{N}=74)$ adolescents were recruited from afterschool programs run by local nonprofit organizations and charter schools. Of the initial 74 youth, five were older than 18 years and were therefore dropped from the current analyses, resulting in a total sample size of 69 youth for the current study. The youth ranged in age from 13-18 years with a mean age of $16.04(\mathrm{SD}=1.50)$. The majority of participants were female $(54 \%)$ and self-identified as being of Mexican descent (74\%). In addition, $12 \%$ of participants self-identified as American Indian, reporting tribal affiliations including Yaqui, Tohono Oodham, Atalling, and Pima, and $12 \%$ selfidentified as being of mixed ethnic heritage.

\section{Procedure}

As part of the University of Arizona Institutional Review Board approved informed consent procedure, youth read and signed a consent form before completing the study survey. Bilingual and bicultural survey administrators administered a 23-item survey, in English, to youth participants during afterschool program time. The survey asked youth to self-report their texting and internet use behaviors. Completion of the survey was completely voluntary and the identity of youth respondents was kept anonymous. Youth who chose not to participate in the study were given other activities to engage in while youth respondents completed the survey.

\section{Measures}

Demographics. Youth were asked to provide their age, gender, and ethnicity. Youth were able to choose from more than one ethnic category based on the following list of options: Mexican American, Mexican National, American Indian, Asian American, African American, White (Caucasian/non-Hispanic), and Other. Youth were also asked to indicate whether they qualify for or receive a free or reduced lunch at school, with response options including "yes," "no," "don't know," or "no longer in school."

Cell phone access. The survey contained two items (i.e., "Do you have your own cell phone?" and "Do you ever borrow someone else's cell phone?") related to cell phone access. Response options for both items were either "yes" or "no." If youth indicated that they borrowed a cell phone, they were asked an additional item about from whom they borrowed the cell phone. Responses for this item included "family member," "friend," "boyfriend/girlfriend," or "other please specify."

Cell phone use. Two items asked about participant cell phone use ("How many times have you changed your cell phone number?", "How often do you use your cell phone?") and response options ranged from "several times a day" to "emergencies only."

Text messaging. There were a total of eight items related to text messaging. Two items asked about the sending and receiving of text messages and response options included "yes", "no" or "my cell can't send/receive text messages." Two items asked about how often youth 
send and receive text messages with responses ranging from "never" to "five or more times a day." Two items asked about from whom text messages were received and to whom text messages were sent. Response options included (a) parents/guardians, (b) brother/sister, (c) other relatives, (d) friends, (e) boyfriend/girlfriend, ( $f$ ) advertisements, and ( $g$ ) other. Two items asked about unlimited texting and monthly limits on texting.

Parental rules about cell phone and texting. Two items inquired about parental rules related to cell phone and texting use (e.g., "Do your parents have any rules about cell phone use/texting?"). Response options included "yes" or "no" with a space provided for respondents to elaborate if they answered affirmatively to the item.

\section{Results}

\section{Cell Phone Access and Use}

The majority of participants $(71 \% ; n=49)$ reported that they have their own cell phone. Of the 20 youth who reported not owning a cell phone, $55 \%(n=11)$ reported that they borrow others' cell phones. Based on t-test analyses, there were no significant age or gender differences among participants who did or did not own their own cell phones. Of the youth who reported qualifying for free lunch $(n=47), 68 \%$ reported having their own cell phone. Among participants who had cell phones, $46 \%$ had never changed their cell phone number, $13 \%$ had changed it once, and $41 \%$ had changed it two or more times. Seventy six percent $(n=47)$ of the entire sample reported that they use their cell phone several times a day, while only $3 \%(n=7)$ reported that they use it only for emergencies.

\section{Texting Behaviors}

The majority $(80 \%)$ of respondents reported that they have unlimited text messaging plans. Eighty eight percent $(n=53)$ of participants receive text messages and $88 \%$ send text messages. Eighty two percent $(n=48)$ reported that they receive text messages four or more times a day, whereas only $9 \%$ reported never receiving text messages. Of the youth who receive text messages, $75 \%$ reported receiving texts from their friends, $47 \%$ from a boyfriend/ girlfriend, $28 \%$ from siblings, $24 \%$ from parents, $20 \%$ from other relatives, and $2 \%$ from advertisers. Based on t-test analyses, no significant gender differences were found for any of the texting variables.

\section{What Predicts Receiving/Sending More Text Messages?}

T-test analyses were conducted to assess differences in the amount of texts sent from and received by participants based on the persons from whom they were receiving texts. Youth who received texts from boyfriends/girlfriends $(n=28)$ were significantly more likely to report receiving more texts $(t=-3.70, p<.001)$ and sending $(t=-4.31, p<.001)$ than youth who did not receive texts from boyfriends/girlfriends. Youth who received texts from boyfriends/girlfriends report receiving $(M=6.89, S D=.32)$ and sending $(M=4.89, S D=.42)$ more texts compared to youth who did not receive texts $(M=4.97, S D=2.88)$ or send texts $(M=3.26, S D=2.07)$ from boyfriends/girlfriends.

The majority of youth $(65 \% ; n=45)$ reported receiving texts from friends, and compared to youth who did not receive texts from friends, there were significant differences in receiving $(t=-3.06, p<.01)$ and sending texts $(t=-3.17, p<.01)$. Youth who received texts from friends were significantly more likely to receive texts $(M=6.53, S D=1.4)$ and send texts $(M=4.51$, $S D=1.18)$ compared to youth $(n=14)$ who did not receive texts from their friends $(M=3.79$, $\mathrm{SD}=3.26 ; \mathrm{M}=2.50, \mathrm{SD}=2.28$, respectively). 
No significant differences were found regarding the amount of texts received and sent for youth who received texts from family members (e.g., parents, siblings, and other relatives). Only 14 youth reported receiving texts from their parents. There were no differences in the amount of texts received or sent by adolescents who received texts from their parents compared to those who did not receive texts from their parents (frequency of cell use: $t(60)=-.99, p=.32$; texts received $t(60)=-1.24, p=.22$; texts sent $t(60)=-1.10, p=.28)$.

\section{Parental Rules for Cell Phone or Texting Use}

Seventeen percent of respondents reported that their parents had rules regarding their cell phone use. Even fewer respondents $(12 \% ; n=7$,$) reported having any parental rules about$ texting. Among youth who reported that their parents had rules regarding their cell phone use, the majority (70\%) were female and ranged in age from 13-18 years.

Results from an open-ended survey item allowed youth to describe their parents' rules about cell phone use. Youth reported that these rules included "nothing bad," and typically included issues of time limitations (e.g., "off by nine", "not to stay on my phone too late at night", "not after 11 ", "not after 9 p.m. on weekdays"), etiquette ("no cuss words"), and cell phone usage and expenses ("don't go over the minutes"). Among youth who reported having parental rules regarding texting, these rules primarily related to etiquette ("no cuss words" and "no bad language").

\section{Discussion}

The purpose of this study was to investigate the existence of parental rules about cell phone and text messaging among a low income sample of ethnic minority adolescents. Our results indicate that the majority of youth owned cell phones (71\%) or borrowed cell phones and used them multiple times a day (76\%) while only $3 \%$ use them only in the event of an emergency. Eighty two percent of participants report receiving text messages more than four times a day; high rates of daily text messaging was associated with texting friends or romantic others. Twenty four percent of texts received were sent from parents. Only $17 \%$ of the sample reported having any parental rules related to cell phone use and only $12 \%$ identified having parental rules related to texting. The majority of the teens who did report parental rules were typically females. Of those who reported having parental rules regarding cell phone use, the rules were primarily based on how late in the day teens could use the phone and on using proper language in text messages.

National studies (D'Antona, Kevorkian, \& Russom, 2010; Lenhart, 2012; Lenhart, 2010) have begun to investigate cell phone and texting use among adolescents; however, very little is known about cell phone use among ethnic minority adolescents and monitoring of adolescents' cell phone use by parents. Our study clearly indicates that cell phone and texting behaviors are common even among low income Latino adolescents. The rates of use increase when adolescents have romantic partners. However, the use of media by parents is relatively low and teens report little to no parental monitoring of cell phone use. Even the monitoring that is reported is minimal and is related to how late in the evening teens can use media. No participants mentioned that parents have rules for internet use, sexting, or texting while driving.

It is critical to better understand cell phone and texting usage among low income ethnic minority adolescent given the prevalence of use in the general population and potential vulnerabilities youth face related to cyberbullying and sexting (D'Antona, et al., 2010; Rivers, \& Noret, 2010). Recently much attention has been paid to the negative influence that sexting and 
cyber bullying can have on adolescent health (D'Antonia, Kevorkian, \& Russom, 2010; Li, 2006), which may reflect a greater need for parents to be more engaged and to monitor more closely adolescent cell phone use, particularly given the higher rate of communication with romantic partners.

The measures in the current study are limited as there are very few standardized measures of media use. The measures used in the current study offer a starting point to begin to quantify and identify patterns of cell phone and texting use. Moreover, future studies should consider including standardized measures of parental monitoring and risky behaviors. Furthermore, sampling both adolescents and their parents will more clearly demonstrate parental monitoring and the impact on teen media use and risky behaviors.

While generalizations based on the current study are limited given the sample size and the specificity of the demographics, it does begin to shed light on the reality that low income ethnic minority adolescents are highly engaged in cell phone use. Moreover, parents may be providing few, if any, rules for use and may not be engaging in sufficient parental monitoring of their children's cell phone and texting use. Given the recent attention regarding the use of text messages for cyberbullying and sexting (D'Antona, et al., 2010; Rivers, \& Noret, 2010) the current study provides preliminary evidence for the need to raise awareness among parents about potential risks regarding adolescent cell phone use and to target parental monitoring practices.

\section{References}

Bird, H.R., Canino, G.J., Davies, M., Zhang, H., Ramirez, R. \& Lahey, B. (2001). Prevalence and correlates of antisocial behaviors among three ethnic groups. Journal of Abnormal Child Psychology, 29, 465-478.

Caprara, G.V., Scabini, E., Barbaranelli, C. Pastorelli, C., Regalia, C., \& Bandura, A. (1998). Impact of adolescents' perceived self-regulatory efficacy on familial communication and antisocial conduct. European Psychologist, 3, 125-132.

Dinh K., Roosa M., Tein J., \& Lopez V. (2002). "The Relationship Between Acculturation and Problem Behavior Proneness in a Hispanic Youth Sample: A longitudinal mediation model," Journal of Abnormal Child Psychology, 30, 295-309.

Dishion, T.J., \& McMahon, R.J. (1998). Parental monitoring and the prevention of child and adolescent problem behavior: A conceptual and empirical formulation. Clinical and Family Psychology Review, 1, 61-75.doi:10.1023/A:1021800432380.

Donahue, E.H., Haskins, R., \& Nightingale, M. (2008). Using media to promote adolescent wellbeing. The Future of Children, Spring, 1-7.

D’Antona, R., Kevorkian, M., \& Russom, A. (2010). Sexting, texting, cyberbullying and keeping youth safe online. Journal of Social Sciences, 6(4), 523-528.

Jacobson, K.C., \& Crockett, L.J. (2000). Parental monitoring and adolescent adjustment: An ecological perspective. Journal of Research on Adolescence, 10, 65-97. doi:10.1207/SJRA1001_4.

LeDoux, S., Miller, P., Choquet, M., \& Plant, M. (2002). Family structure, parent-child relationships, and alcohol and other drug use among teenagers in France and the United Kingdom. Alcohol \& Alcoholism, 37, 52-60. 
Lenhart, A. (2012). Teens, Smartphones, and Texting. Pew Research Center: Pew Internet and American Life Project. 1-34.

Lenhart, A., Ling, R., Campbell, S., \& Purcell, K. (2010). Teens and mobile phones. Pew Research Center: Pew Internet and American Life Project. 1-20.

Li, Q. (2006). Cyberbullying in schools: A research of gender differences. School Psychology International, 27, 157-170.

Patterson, G.R., Dearyshe, B.D., \& Ramsey, E. (1989). A developmental perspective on antisocial behavior. American Psychologist, 44, 329-335.

Pettit, G.S., \& Laird, R.D. (2002). Psychological control and monitoring in early adolescence: The role of parental involvement and earlier child adjustment. In B.K. Barber (Ed.), Intrusive parenting: How psychological control affects children and adolescents (pp. 97-123).

Washington, DC: American Psychological Association.

Pew Research Center: Pew Internet and American Life Project. (2012). Teens, smartphones \& texting. Washington, DC: Lenhart, A.

Pew Research Center: Pew Internet and American Life Project. (2010). Teens and mobile phones. Washington, DC: Lenhart, A., Ling, R., Campbell, S., \& Purcell, K.

Romero, A.J., \& Ruíz, M.G. (2007). Does familism lead to increased parental monitoring?: Protective factors for coping with risky behaviors. Journal of Child and Family Studies, 16, 143154.

Rivers, I., \& Noret, N. (2010). 'I h8 u': Findings from a five-year study of text and email bullying. British Educational Research Journal, 36(4), 643-671.

Stattin, H., \& Kerr, M. (2000). Parental Monitoring: A Reinterpretation. Child Development, 71, 1072-1085.

Uy-Tioco, C. (2007). Overseas Filipino workers and text messaging: Reinventing transnational mothering. Continuum: Journal of Media \& Cultural Studies, 21, 253-265.

Van Campen, K.S., \& Romero, A.J. (2012). How are self-efficacy and family involvement associated with less sexual risk-taking among ethnic minority adolescents? Family Relation, 61(4), 548-558.

Weisskirch, R. (2011). No crossed wires: Cell phone communication in parent-adolescent relationships. Cyberpsychology, Behavior, and Social Networking, 14, 447-451.

Weisskirch, R. (2009). Parenting by cell phone: Parental monitoring of adolescents and family relations. Youth Adolescence, 38, 1123-1139.

(C) Copyright of Journal of Youth Development Bridging Research and Practice. Content may not be copied or emailed to multiple sites or posted to a listserv without copyright holder's express written permission. Contact Editor at: patricia.dawson@oregonstate.edu for details. However, users may print, download or email articles for individual use.

ISSN 2325-4009 (Print); ISSN 2325-4017 (Online) 


\section{Appendix A:}

Survey Items Regarding Cell Phone Use

\section{Item}

Do you have your own cell phone?

Do you ever borrow someone else's cell phone?

answered YES, that you do borrow a cell phone from others, please check all those that you borrow cell phones from:

How many times have you changed your cell phone number?

How often do you use your cell phone?

Do you receive text messages?

Do you send text messages?
Yes

No

My phone can't receive text messages

\section{Response Options}

Yes

No

Yes

No

I do not borrow other people's cell phone

Family member (specify)

Friend

Boyfriend/Girlfriend

Other (specify)

Never

Once

Two times

Three times

Four times

Five or more times

Several times a day

Once a day

Once a week

On the weekends

Emergencies only

Other (specify)

Yes

No

My phone can't receive text messages 
How often do you receive text messages in one day?

Never

Once a month

Once a week

Once a day

Two times a day

Three times a day

Four times a day

Five or more times a day

From whom do you usually receive text messages (check all that apply)

Parents or Guardians

Brother/Sister

Other relatives (specify)

Friends

Boyfriend/Girlfriend

Advertisements

Other (specify)

How often do you send text messages?

Never

Once a day

Two times a day

Three times a day

Four times a day

Five or more times a day

Do you have unlimited texting per month?

Yes

No

If no, what is your monthly limit?

I don't receive text messages

50

$100-200$

$300-400$

$500-600$

$700-1000$

Do your parents have any rules regarding your cell phone usage?

No

Yes (specify)

Do your parents have any rules regarding texting?

No

Yes (specify) 